\title{
Considering choline as methionine precursor, lipoproteins transporter, hepatic promoter and antioxidant agent in dairy cows
}

\author{
Imtiaz Hussain Raja Abbasi', Farzana Abbasi², Rab N. Soomro' ${ }^{1}$, Mohamed E. Abd El-Hack², \\ Mervat A. Abdel-Latif ${ }^{4}$, Wen Li' ${ }^{1}$, Ren Hao' ${ }^{1}$ Feifei Sun' ${ }^{1}$, Bello M. Bodinga ${ }^{1}$, Khawar Hayat $^{1}$, Junhu Yao' \\ and Yangchun $\mathrm{CaO}^{1 *}$
}

\begin{abstract}
During the transition period, fatty liver syndrome may be caused in cows undergo negative energy balance, ketosis or hypocalcemia, retained placenta or mastitis problems. During the transition stage, movement of non-esterified fatty acids (NEFA) increases into blood which declines the hepatic metabolism or reproduction and consequently, lactation performance of dairy cows deteriorates. Most of studies documented that, choline is an essential nutrient which plays a key role to decrease fatty liver, NEFA proportion, improve synthesis of phosphatidylcholine, maintain lactation or physiological function and work as anti-oxidant in the transition period of dairy cows. Also, it has a role in the regulation of homocysteine absorption through betaine metabolite which significantly improves plasma a-tocopherol and interaction among choline, methionine and vitamin E. Many studies reported that, supplementation of rumen protected form of choline during transition time is a sustainable method as rumen protected choline (RPC) perform diverse functions like, increase glucose level or energy balance, fertility or milk production, methyl group metabolism, or signaling of cell methionine expansion or methylation reactions, neurotransmitter synthesis or betaine methylation, increase transport of lipids or lipoproteins efficiency and reduce NEFA or triacylglycerol, clinical or sub clinical mastitis and general morbidity in the transition dairy cows. The purpose of this review is that to elucidate the choline importance and functions in the transition period of dairy cows and deal all morbidity during transition or lactation period. Furthermore, further work is needed to conduct more studies on RPC requirements in dairy cows ration under different feeding conditions and also to elucidate the genetic and molecular mechanisms of choline in ruminants industry.
\end{abstract}

Keywords: Choline, Fatty liver, Dairy cows, Production, Transition period

\section{Introduction}

Feed formulation technology, ingredients concentration or nutrient requirements, according to need and stage of animals play an important role in the production and health of ruminants. Excessive or unbalanced amount of nutrients or ingredients may cause disease, reduce dairy performance and increase the environmental pollution. Cows are suffering from different physiological

\footnotetext{
*Correspondence: caoyangchun@126.com

${ }^{1}$ Department of Animal Nutrition and Feed Science, College of Animal Science and Technology, Northwest A\&F University, Yangling 712100, Shaanxi, People's Republic of China

Full list of author information is available at the end of the article
}

variation throughout the transition period i.e. reduction of dry matter intake, go into negative energy or metabolizable protein balance, increase the demand of high quality nutrients to sustain growth of fetus and lactation performance, development of ketosis, hypocalcemia, clinical mastitis and fatty liver signs (Overton and Waldron 2004; Esposito et al. 2014; Itle et al. 2015; Sun et al. 2016). Through the transition stage, stress and hormonal variations enhanced non-esterified fatty acids (NEFA) into blood to overcome negative energy balance in transition cows. NEFA oxidation occurs in the liver in order to generate energy and some will renovate into triglyceride (TG) and mobilize in the form of very 
low-density lipoprotein (VLDL) (Pinotti et al. 2003). But, some of the NEFA is partially oxidized in the liver and consequently increased ketone bodies in the blood and export of TG through VLDL become limited. Furthermore, in pre-or early lactation cows peroxidation ratio of lipid was increased (Castillo et al. 2005) but serum $\alpha$ tocopherol was reduced (LeBlanc et al. 2004) and then, oxidative stress at higher levels which decreased the health of dairy cows and their productive performance (LeBlanc et al. 2004). Choline also works as an antioxidant in transition cows, it has antioxidant properties that protect cell and reduce the free radical production which damage liver cells (Elsawy et al. 2014). During the transition period, supplementation of RPC and rumen protected methionine (RPM) alleviate the oxidative stress throughout the period (Wu et al. 2013) and increase the immune response through its antioxidant activities on immune organs (Wua et al. 2014; Sun et al. 2016). Choline $\left.\left[\left(\mathrm{CH}_{3}\right)_{3} \mathrm{~N}+\left(\mathrm{CH}_{2}\right)_{2} \mathrm{OHX}\right)\right]$ also called as trimethyl ethanolamine categorized as B-complex vitamin, but this is not satisfactory definition or category of choline (Zeisel and Da Costa 2009). Because choline is endogenously synthesized agent and its deficiency syndrome is very difficult to be recognized in ruminant, because it has complex interaction with methionine, folic acid and vitamin $\mathrm{B}_{12}$. Sometimes, when methionine and folates deficient diet offered to ruminants, the choline works as an essential nutrient for ruminants (Zeisel 2000). Supplementation of rumen unprotected form of choline is quickly degraded by rumen microbes and the remaining quantity can't reach to the level for absorption or maintaining further functions. So, rumen protected choline must be supplemented in the rations of cows; to continue choline dependent key mechanisms like, sustaining of animal metabolism, sparing of methyl group and remethylation of homocysteine through betaine metabolite (Esposito et al. 2014; Itle et al. 2015). The present review article aimed to highlight the choline functions and importance in the transition period of dairy cows and deal all morbidity during transition or lactation period.

\section{Physiological functions of choline and its important action in cell \\ Choline metabolites and their key role in cells}

Choline is categorized as an essential nutrient in dairy ruminants but their logic mechanisms are still challenging and it transformed into several metabolite forms in cells for optimal growth or performance in addition to ideal health of cows (Phillips 2012). Phosphatidylcholine (PC), lysophosphatidylcholine (LPC), free choline (Cho) and sphingomyelin (SM) are the key constituents as choline containing lipid soluble metabolite for all cell membranes and have an important role in the cell signaling and lipid metabolism (Jiang et al. 2014). Choline or its metabolites are important to maintain the important physiological functions i.e. cell membrane structural veracity and signaling roles, synthesis of acetyl choline (neurotransmission) and methylation to transfer methyl group through it betaine metabolite to synthesize S-adenosylmethionine (SAM) pathway (Glier et al. 2014). Choline metabolites play a vital role in the mammalian biological development particularly; its supplementation during the transition period increases the metabolism of lipids in the hepatic cells (Veth et al. 2016). Cho, acetylcholine (ACho), glycerol phosphorus choline (GPCho), betaine (Bet), and phosphorus choline (PCho) as water-solubles serving as basic neurotransmitters in the autonomic nervous system with ACho (Cheng et al. 2008; Artegoitia et al. 2014). However, during mitochondrial oxidation of Cho, form Bet with GPCho are produced and act as organic osmolytes (Jiang et al. 2014). Furthermore, Bet undergoes oxidation in order to release methyl groups for translation of homocysteine and generation of methionine (Eklund et al. 2005; Combs 2012). Because of the complex function or action of choline and its metabolites in the cell, further research is still needed to find out the individual effects of choline metabolites on the blood plasma, milk production or composition during pre-or post-parturient period and their effect on hepatic cells.

\section{Betaine as transmethylation agent}

Betaine is the most vital choline metabolite (Betaine) which is important for synthesis of creatine, carnitine or methionine by methyl group donation through transmethylation pathway into cell (Eklund et al. 2005). Most of dietary products are rich sources of phosphatidylcholine, approximately contain $13 \%$ Cho by weight (Koc et al. 2002). Supplementation of choline in the ration can significantly affects the re-methylation activity of Bet, although, Bet can't go into reverse reaction to convert back into choline but it takes a part when Cho is not abundant to maintain re-methylation reaction for homocysteine synthesis (Siljander et al. 2003). Ration supplemented with Bet can modulate methylation through homocysteine methyltransferase reaction, which regulate $S$-adenosylhomocysteine and $S$-adenosyl methionine in the cell and also improve epigenetic mechanism or methylation of DNA in the cell, availability of choline or betaine in the ration with other methyl donor group can significantly influence the methylation reactions (Zeisel 2017). Furthermore, methyl-tetrahydrofolate and betaine actively participate in the biosynthesis methylation of homocysteine to methionine (Zeisel 2017). 


\section{Labile role of choline and methionine}

Methionine (Met) is considered as a top limiting amino acid (AA) for milk production and it is a good opportunity to supplement rumen undegraded form of methionine in the ration of dairy cows typically in order to improve milk or milk protein production, sustain contribution of SAM molecules for choline synthesis and enhance VLDL production to reduce ketones body during the early lactation period in dairy ruminants (Overton et al. 1998). In addition, both of Met and Cho are important nutrients as methyl moiety providers in ruminants. Met works as a methyl donor to endorse de novo synthesis of Cho and supplementation of Cho contributes to spare betaine metabolite for generation of sulphur containing AA (Met) as to support animal performance (Ardalan et al. 2011). Actually, Cho is a donor of Bet and Bet provide methyl group for conversion of homocysteine to provide Met which require 5 methyl tetrahydrofolate through betaine homocysteine methyl transferase enzyme (Zeisel and Corbin 2012). Then homocysteine undergoes further catabolism mechanism to produce cysteine through vitamin $B_{6}$ transsulfuration dependent pathway (Fig. 1) or sometimes remethylated to methionine. But the quantity of folate, and Cho in blood and liver significantly affect the homocysteine regulation pathway (Leach et al. 2014). Vitamin B complex group (riboflavin, $\mathrm{B}_{6}, \mathrm{~B}_{12}$ and folate) and Cho are compulsory for both AA and nucleic acids metabolism and take an important role in the synthesis of SAM as universal donor from Met. For methylation reaction, SAM contributes three molecules that changed phosphatidylethanolamine into phosphatidylcholine by phosphatidylethanolamine $N$ methyl transferase enzyme, then further phosphatidylcholine generates choline by the action of phospholipases through cytidine diphospho choline pathway (Fig. 2) and becomes $S$-adenosylhomocysteine which further converted into homocysteine. Once homocysteine is formed, it will be metabolized into cysteine through transsulfuration vitamin $\mathrm{B}_{6}$ dependent pathway (Fig. 1) (Osorio et al. 2014).

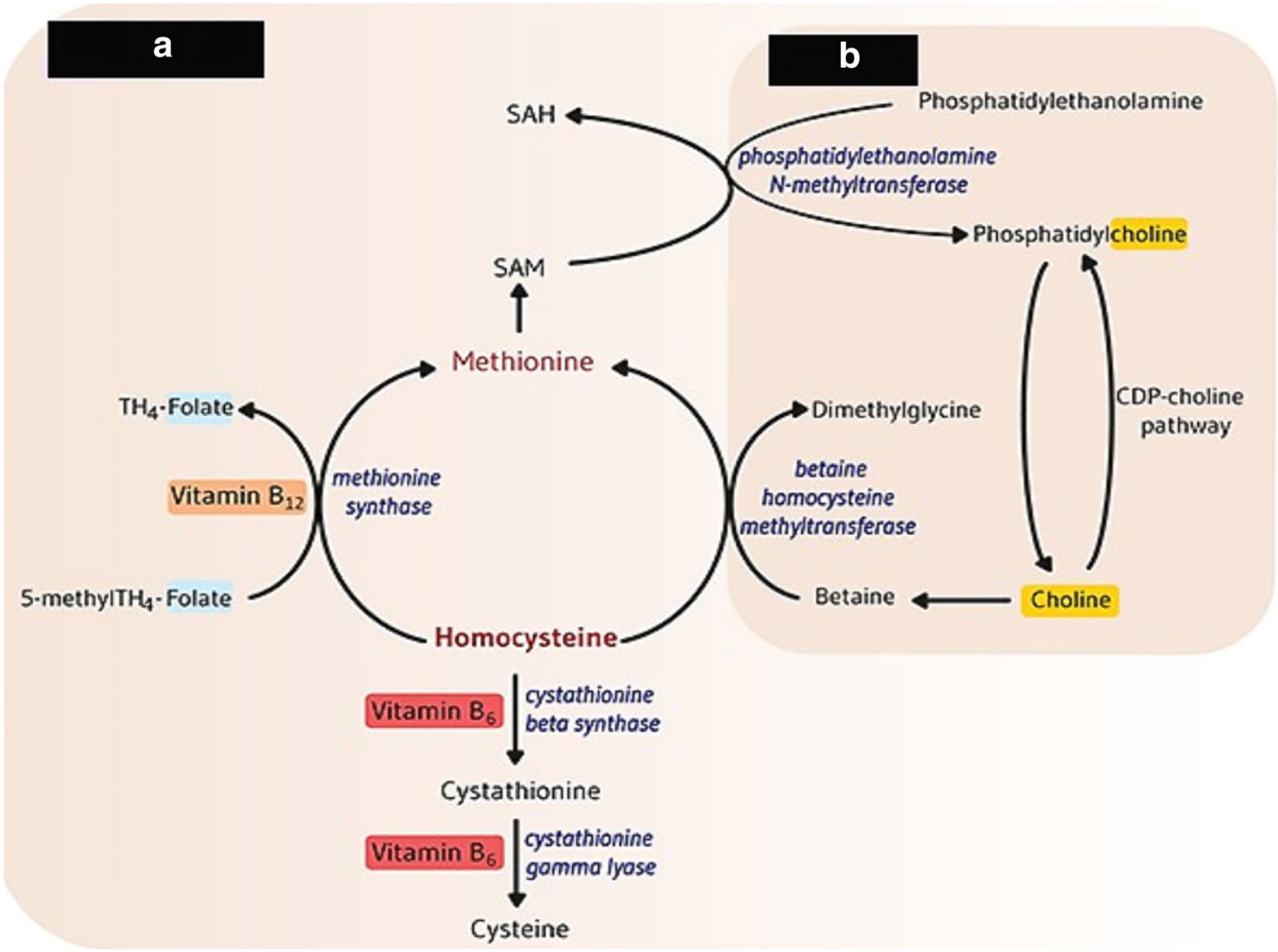

Fig. 1 a Methylation reaction pathway of homocysteine, to form essential amino acid methionine and another choline metabolite betaine, dependent pathway as methyl donor for methylation of homocysteine for methionine formation and $\mathbf{b}$ demonstrated that methionine as a universal donor of S-adenosyl methionine (SAM) which contribute to convert phosphatidylethanolamine into phosphatidylcholine to generates choline 


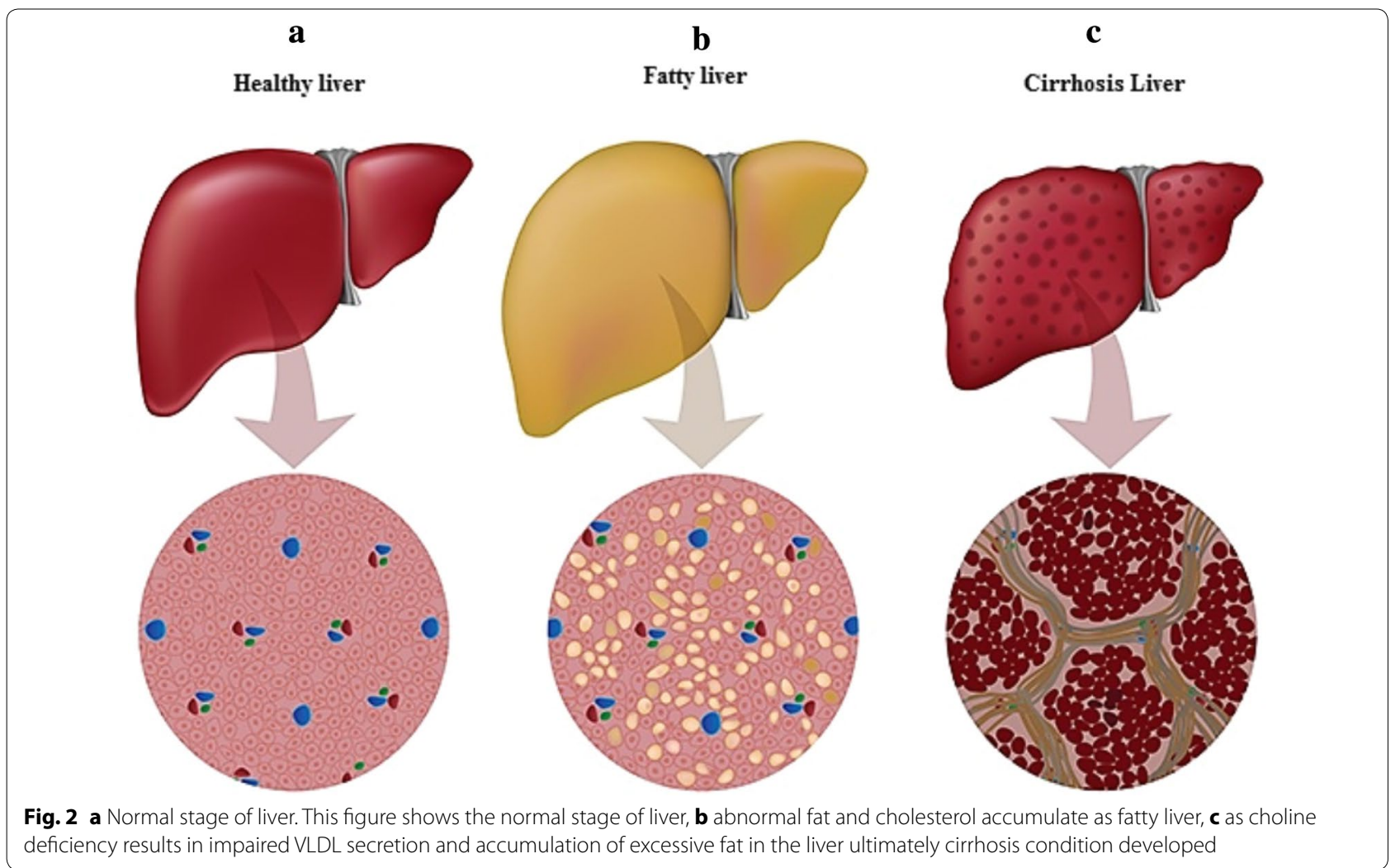

\section{Choline impacts on NEFA production and hepatic function in transition cows \\ Non-esterified fatty acids as an energy indicator of transition cows}

During the transition period, the traditional management of dairy farm provides cows stress free environment, which directly reduce mobilization or circulation of NEFA from the adipose tissue; NEFA concentration directly reflect mobilization of adipose tissue, these fatty acids circulate in the blood to maintain energy balance during the transition period (McNamara 1991). Calving is stressful condition in which NEFA and hydroxyl butyric acids concentrations were increased which are specific to negative energy balance and then, reduction of milk yield, development of fatty liver syndrome in addition to postpartum reproductive problems in cows (Grummer 2008). During the transition period, high producing cows have rapid transportation of fatty acids from adipose tissue to maintain energy balance resulting in circulation of excess NEFA in the blood which impair the hepatic function and animal performance with increase in choline metabolism (Karimian et al. 2015). Through stress, adipocytes are lipase sensitive, and the deposited triacylglycerol is broken down into glycerol and nonesterified fatty acids or free fatty acids which transported into liver, if continuous NEFA mobilization increase towards liver which directly causes hepatic inflammation or hepatic steatosis and the liver function decreased (Maison et al. 2000; Zhang et al. 2005). Continuous and excessive mobilization of the stored fatty acids from adipose tissue is a sign of low dietary energy which increase burden on liver with low hepatic fatty acid oxidation rate and low mobilization rate of VLDL (Grummer 1993). Furthermore, high uptake of NEFA by hepatic cell consequently develop hepatic lipidosis condition of cows and alleviate the capacity of detoxifying ammonia into urea which reduces gluconeogenic capacity from propionate fatty acid (Strang et al. 1998). Liver cell capacity fully engaged to esterify mobilized NEFA into TAG (Litherland et al. 2011). Excessive overload of NEFA accelerated the oxidation level of liver cells and secretion of esterified fatty acids (or TAG) in the form of VLDL and finally TG accumulation will be start and liver will go into impaired condition, fatty liver syndrome or cirrhosis condition will be developed and cows' health or performance will be down every day (Drackley et al. 2005). To control this situation, increase production of VLDL or lipoprotein in the transition cows through rumen protected choline (RPC) supplementation which has a good opportunity, to alleviate fatty liver disorder, reduce ketosis in lactating cows and improve milk composition or yield (Reynolds et al. 2003; Castillo et al. 2005; Cooke et al. 2007). 


\section{The supplemented RPC affects the health and fatty liver syndrome}

Fatty liver is a general sign during the transition period of dairy cows. Several steps were taken to reduce this syndrome, rumen protected choline supplementation is one of the best steps to export hepatic fat by lipoprotein pathway and improved performance of dairy cows (Zom et al. 2011; Ardalan et al. 2011; Elek et al. 2013). Choline has significant effects on general function of animal body particularly on the immunity of liver cells. During calving, hormonal variations and negative energy balance during transition or following early lactation are significant condition of higher liver uptake of NEFA which cause overload on the liver to metabolize the esterified fatty acids (Goselink et al. 2012). Feeding ration containing deficient ratio of both Cho and Met leads to decrease of vitamin $\mathrm{C}$ or $\alpha$ or $\gamma$ tocopherol production which causes infection of epithelium, degeneration of muscle and damage of hepatic tissue with decrease of VLDL hepatic transportation (Henning et al. 1997). The amount of dietary fat or cholesterol affect the production of NEFA during stress condition which mobilized into hepatic cells through lipoprotein termed as chylomicrons pathway; then these fats or cholesterol wrapped named as very low-density lipoprotein (VLDL) and carried to liver through blood stream, but VLDL assembly or secretion from hepatic cell need phosphatidylcholine (Noga and Vance 2003). If phosphatidylcholine is not in abundant amount, the impaired VLDL secretion will start and accumulation of fat or cholesterol in hepatic cells will start and then fatty liver condition will develop, finally liver cells undergo steatosis and cirrhosis (Noga et al. 2002). Although concentration of foliate significantly increases demand of Cho derivative and Bet; if the ration is deficient in dietary foliate and Cho, the de novo synthesis also does not maintain body requirement of choline. Conversely, VLDL, Bet or Met balance undergoes stress and liver performance will go down (Noga et al. 2002). Choline deficiency showed atherosclerosis sign or liver function disorder and increase the quantity of liver enzyme alanine amino transferase (MIC 2017). In addition, its deficiency elevates the homocysteine level and raise the risk of dystocia or retained placenta, low fetus weight and promote inflammation of hepatic cells or cause lipid metabolism disorder, increase oxidative stress or reactive oxygen species (Zeisel and Da Costa 2009; Sun et al. 2016). Most species showed fatty liver syndrome due to dietary Cho deficiency, which is developed due to deposition of fat or triacylglycerol which decrease phosphatidylcholine, conversely, VLDL synthesis or secretion will go in termination pathway (Jiang et al. 2014). Transition period of dairy ruminants categorized as low or high fatty liver period (Bobe et al. 2004), supplementation of
RPC decline deposition of triacylglycerol and increase genes expression which involved in VLDL mobilization (Zom et al. 2011). More recent studies reported that, basic bovine hepatocytes improve VLDL transportation when incubated with Cho chloride (Goselink et al. 2013).

\section{RPC applications and their effects on performance of cows Effects of supplemented RPC on hematology and reproductive performance of cows}

During the transition period, cows undergoes many physiological changes, production and metabolism of NEFA is a big challenge and the total plasma bilirubin (TBIL) concentration in the blood shows liver lipidosis conditions or liver dysfunction, during postpartum period, the concentration of TBIL of cows were found significantly high (Bionaz et al. 2007; Sejersen et al. 2012). Supplementations of RPMet and RPC particularly in the transition cows improved the hepatic function, and decreased the concentration of TBIL which showed as the sign of healthy liver status (Sejersen et al. 2012; Sun et al. 2016). In dairy cows, metabolism of free radicals remains under homeostatic condition, but in transition period, due to excessive stress, production of higher NEFA concentration and their oxidation at the hepatic cell, increase reactive oxygen species (ROS) which result in oxidative stress (Bionaz et al. 2007; Turk et al. 2013). During the transition period, supplementation of both RPC and RPMet, in plasma increases the total antioxidant capacity (T-AOC) and vitamin $\mathrm{E}$ concentration, but malondialdehyde content was decreased. (Sun et al. 2016). Furthermore, dietary RPC supplementation in cows had significant effects a increased serum glucose and cholesterol concentration and reduced triglyceride, NEFA and urea concentration (Soltan et al. 2012) but decreased plasma cholesterol, triglycerides percent, and glucose (Piepenbrink and Overton 2003). On the other hand, some contrast studies report that, supplementation of RPC found no significant effect on NEFA, glucose, total protein, albumin, globulin urea- $\mathrm{N}$ and $\beta$ hydroxybutyric acid (BHBA), because there was no variation in adipose tissue mobilization or production of BHBA in the hepatic cell was found during RPC supplementation (Zahra et al. 2006; Guretzky et al. 2006). Many studies noted that, the incidence of reproductive disorder was increased during the transition period increased due to excessive mobilization of adipose tissue for synthesis milk fat, and decline the development of follicle which indicates low fertility. However, supplementation of RPC had no significant effects on pregnancy, insemination, per conception ratio and estrus cycle compared to control (Ardalan et al. 2011; Lima et al. 2012). Moreover, ration supplemented with RPC and RPMet decreases overall frequency of heath disorder during the transition period (Xu et al. 1998), compared to 
control group cows supplemented with RPC cows calving twins (Guretzky et al. 2006).

\section{Impact of supplemented RPC on milk yield and properties of cows}

Both quantity and quality of milk are the most important traits of ruminants industry. Supplementation of $\mathrm{RPC}$ can increase both traits due to higher digestibility, improve VFA production, reduce $\mathrm{NH}_{3}-\mathrm{N}$ or ketosis metabolic disorder and decrease fatty liver syndrome (Baldi and Pinnotti 2006). Further intestinal Cho supplementation improves milk performance in dairy cows about 7\% more than control (Ardalan et al. 2011). Many studies reported that, supplementation of RPC increased the tendency of milk production, and fat corrected milk in lactating dairy cows (Lima et al. 2007). Cho supplementation works as a significant lipotropic agent in dairy ruminants, as it reduces excessive fat accumulation in the hepatic cells with significant and increase in milk yield, fat, lactose, solid not fat, total solid and protein yield (Zom et al. 2011; Leiva et al. 2015). Milk production, fat and protein were improved when ration supplemented with RPC and RPMet during transition period of cows (Osorio et al. 2013; Sun et al. 2016). Although, some studies reported that supplementation of RPC significantly can't improve milk yield or fat corrected milk (Pinotti et al. 2003; Pineda and Cardosa 2015). RPC supplementation in dairy cows could not have significant effects on milk fat, protein, lactose, SNF, total solids, yield and milk urea nitrogen concentration compared to control (Xu et al. 2006; Zom et al. 2011). Supplementation of RPC had no positive effects on milk lactose and other milk components (Hartwell et al. 2000; Guretzky et al. 2006; Baldi et al. 2011). However, the experimental design (Zahra et al. 2006) supplementation of other diets (Davidson et al. 2008) application methods (Ardalan et al. 2010) animals breed (Sales et al. 2010) quantity of supplements, length of experiment or duration and phase of lactation of dairy cows significantly affect the RPC supplementation and milk production or milk properties (Guretzky et al. 2006). Milk yield, protin, fat and fat corrected milk were increased in Alfalfa and maize silage ration supplemented with RPC as (60 g/day) (Ardalan et al. 2011). Cows supplemented with RPC had significant increase in milk production when compared with cows fed other diets (Davidson et al. 2008).Multiparous Holstein cows supplemented RPC 5 an $100 \mathrm{~g}$ cow/day for 21 pre-parturition and 45 post parturition duration had significant increase in milk fat, protein and total solid also improved haptoglobin and insulin with milk-composition compared with control (Leiva et al. 2015). Primiparous and multiparous Holsteins after lactation for 8 week fed maize silage supplemented with RPC $56 \mathrm{~g} /$ day improved milk yield performance of dairy cows (Zahra et al. 2006). Meta-analysis specified that, RPC supplementation during transition period to cows increased milk yield, fat, protein, because of methylation or methionine sparing, lower liver TGA and improved gluconeogenesis process by hepatic cell (Sales et al. 2010; Goselink et al. 2012) (Table 1).

\section{Choline metabolism and dietary requirements for dairy cows}

Dietary requirements of choline and its importance were recognized in, swine, poultry and fish but till now, many studies under investigation and try to establish the requirements and its important functions in dairy cows during the transition period (NRC 2001). Dietary choline is easily degraded through rumen microorganism and does not maintain the balance or requirements of ruminants so, they must be supplemented with rumen protected choline which bypass rumen degradation process and carry out large amount for absorption at the small intestine (Cheng et al. 2008). Furthermore, due to autonomous processes of absorption of choline metabolites at the small intestine, it makes engaged pathway to understand free choline absorption and supplemented RPC absorption through small intestine and establishes the accurate dietary requirements of choline for dairy ruminants (Cheng et al. 2008). Because absorption pathway of choline is carrier mediated transport pathway and saturable substrate specific at low concentration and passive diffusion mechanism at high concentration (Sheard and Zeisel 1986). Also, choline is absorbed via enterocytes and passes through basolateral membrane mechanism into hepatic portal system (Cheng et al. 2008; Jiang et al. 2014). During periparturient duration supplementation of RPC to cows reverses the deficiency of choline and declines the accumulation of triacylglycerol in the hepatic cells (Zom et al. 2011; Elek et al. 2013). Recently, one study reported that supplementation of RPC $12.5 \mathrm{~g} /$ day reduced the concentration of triacylglycerol by one-third during first 6 weeks of lactation period and improved hepatic performance (Zom et al. 2011). Supplementation of choline ion 18.7 and $37.3 \mathrm{~g} /$ day as RPC at the stage of pre-and postpartum, reduces liver triacylglycerol by $66 \%$ (Elek et al. 2013). The amount of supplemented RPC is an important agenda for future establishing dietary requirements for ruminants; further research focused on how much RPC should be given during the transition period. In previous research broad ranges from (6 to $45 \mathrm{~g} /$ day) of choline chloride has been studied in the transition dairy cows. Although, better response was noted on milk and milk fat or protein and liver fatty syndrome or triacylglycerol which were decreased when RPC was 
Table 1 Summary of different studies supplemented RPC and their effect on milk production, fat and protein $\%$ of dairy cows

\begin{tabular}{|c|c|c|c|c|c|c|}
\hline \multirow[t]{2}{*}{ References } & \multicolumn{2}{|c|}{$\begin{array}{l}\text { Lactation stage } \\
\text { pre-and postpar- } \\
\text { tum days }\end{array}$} & \multirow[t]{2}{*}{ RPC (g/day) supplement } & \multirow[t]{2}{*}{ Milk yield (kg/day) } & \multirow[t]{2}{*}{ Fat yield \% } & \multirow[t]{2}{*}{ Protein yield \% } \\
\hline & Pre & Post & & & & \\
\hline \multirow[t]{3}{*}{ Veth et al. (2016) } & - & 14 & 0 & 31.30 & 4.04 & 3.46 \\
\hline & & & 12.5 & 32.00 & 4.03 & 3.47 \\
\hline & & & 25 & 31.39 & 4.04 & 3.42 \\
\hline \multirow[t]{2}{*}{ Sun et al. (2016) } & 21 & 21 & 0 & - & 3.28 & 3.05 \\
\hline & & & 15 & - & 3.44 & 3.19 \\
\hline \multirow[t]{3}{*}{ Leiva et al. (2015) } & 21 & 45 & 0 & 30.6 & 3.29 & 3.17 \\
\hline & & & $50+$ & 29.1 & 3.51 & 3.32 \\
\hline & & & $100++$ & - & - & - \\
\hline \multirow[t]{2}{*}{ Ardalan et al. (2011) } & 28 & 70 & 0 & 31.70 & 3.30 & 3.13 \\
\hline & & & 60 & 34.60 & 3.35 & 3.11 \\
\hline \multirow[t]{2}{*}{ Davidson et al. (2008) } & 21 & 90 & 0 & 27.90 & 2.97 & 2.60 \\
\hline & & & 40 & 27.50 & 2.93 & 2.68 \\
\hline \multirow[t]{4}{*}{ Piepenbrink and Overton (2003) } & & & 0 & 40.00 & 4.02 & 2.97 \\
\hline & 21 & 63 & 45 & 43.30 & 4.21 & 3.02 \\
\hline & & & 60 & 39.90 & 4.00 & 3.01 \\
\hline & & & 75 & 41.00 & 4.29 & 3.00 \\
\hline \multirow[t]{2}{*}{ Pinotti et al. (2003) } & 14 & 30 & 0 & 28.50 & 3.24 & 3.11 \\
\hline & & & 20 & 31.40 & 3.36 & 3.05 \\
\hline
\end{tabular}

,- not reported; + , supplemented before calving; ++ , supplemented after calving

supplemented from 12 to $20 \mathrm{~g} /$ day to dairy ruminants (Hartwell et al. 2000; Piepenbrink and Overton 2003; Zom et al. 2011; Elek et al. 2013; Itle et al. 2015).

\section{Conclusion}

The role of choline in monogastric (pig, poultry, human) is well understood and documented but in the transition period of dairy cows is still under investigation. The reviewed studies suggested that, considering RPC supplementation levels for best responses were noted to be $12-20 \mathrm{~g} / \mathrm{d}$ of RPC in cows' ration, but the recommended doses during transition period is still unclear. Therefore, the next step is to determine how much RPC should be given at transition period to overcome its related problems and maintain performance of dairy cows. Further epigenetic mechanism and omics technology might be an effective strategy to further understand choline, folate and methionine interaction and their significant functions during transition period.

\section{Abbreviations}

AA: amino acid; ACho: Cho, acetylcholine; Bet: betaine; BHBA: $\beta$ hydroxybutyric acid; Cho: free choline; GPCho: glycerol phosphorus choline; LPC: lysophosphatidylcholine; Met: methionine; NEFA: non-esterified fatty acids; PC: phosphatidylcholine; PCho: phosphorus choline; ROS: reactive oxygen species; RPC: rumen protected choline; SAM: S-adenosylmethionine; SM: sphingomyelin;
T-AOC: total antioxidant capacity; TBIL: total plasma bilirubin; TG: triglyceride RPM: rumen protected methionine; VLDL: very low-density lipoprotein.

Authors' contributions

All authors contributed equally in writing this review article. All authors read and approved the final manuscript.

\section{Author details}

${ }^{1}$ Department of Animal Nutrition and Feed Science, College of Animal Science and Technology, Northwest A\&F University, Yangling 712100,

Shaanxi, People's Republic of China. ${ }^{2}$ School of Life Science and Engineering, Southwest University of Science and Technology, Mianyang 621010, Sichuan, People's Republic of China. ${ }^{3}$ Department of Poultry, Faculty of Agriculture, Zagazig University, Zagazig 44511, Egypt. ${ }^{4}$ Department of Nutrition and Clinical Nutrition, Faculty of Veterinary Medicine, Damanhour University, Damanhour 22516, Egypt.

\section{Acknowledgements}

All authors thank their universities for their help in accomplishing this work.

Competing interests

The authors declare that they have no competing interests.

Availability of data and materials

Not applicable.

Consent for publication

Not applicable.

Ethics approval and consent to participate Not applicable. 


\section{Funding}

The work was partially supported by the National Key Research and Develop ment Program of China (award numbers: 2017YFD0500505), National Natural Science Foundation of China (award numbers: 31472122 and 31672451) and Collaborative Innovation Major Project of Industry, University, Research, and Application in Yangling Demonstration Zone (award numbers: 2016CXY-18).

\section{Publisher's Note}

Springer Nature remains neutral with regard to jurisdictional claims in published maps and institutional affiliations.

Received: 29 September 2017 Accepted: 14 November 2017

Published online: 25 November 2017

\section{References}

Ardalan M, Rezayazdi K, Banadaky MD (2010) Investigation on the effect of supplementing rumen protected forms of methionine and choline on health situation and reproductive performance of Holstein dairy cows. Pak J Biol Sci 12(1):69-73. https://doi.org/10.3923/pjbs.2009.69.73

Ardalan M, Dehghan BM, Rezayazdi K, Hossein ZN (2011) The effect of rumenprotected methionine and choline on plasma metabolites of Holstein dairy cows. J Agric Sci 149:639-646. https://doi.org/10.1017/s0021859610001292

Artegoitia VM, Middleton JL, Harte FM, Campagna SR, Veth MJ (2014) Choline and choline metabolite patterns and associations in blood and milk during lactation in dairy cows. PLoS ONE 9:103-412. https://doi.org/10.1371/ journal.pone.0103412

Baldi A, Pinnotti L (2006) Choline metabolism in high-producing dairy cows: metabolic and nutritional basis. Can J Anim Sci 86:207-212. https://doi. org/10.4141/a05-061

Baldi A, Bruckmaier R, D'ambrosio F, Campagnoli A, Pecorini C, Rebucci R, Pinotti L (2011) Rumen protected choline supplementation in periparturient dairy goats: effect on liver and mammary gland. J Agric Sci 149:655-661. https://doi.org/10.1017/s0021859611000104

Bionaz M, Trevisi E, Calamari L, Librandi F, Ferrari A, Bertoni G (2007) Plasma paraoxonase, health, inflammatory conditions, and liver function in transition dairy cows. J Dairy Sci 90:1740-1750. https://doi.org/10.3168/ jds.2006-445

Bobe G, Young JW, Beitz DC (2004) Invited review: pathology, etiology, prevention, and treatment of fatty liver in dairy cows. J Dairy Sci 87:3105-3124. https://doi.org/10.3168/jds.s0022-0302(04)73446-3

Castillo C, Hemandez J, Bravo A, Lopez AM, Pereira V, Benedito JL (2005) Oxidative status during late pregnancy and early lactation in dairy cows. J Vet 169:286-292. https://doi.org/10.1016/j.tvjl.2004.02.001

Cheng R, MacDonald C, Williams C, Meck W (2008) Prenatal choline supplementation alters the timing, emotion, and memory performance (TEMP) of adult male and female rats as indexed by differential reinforcement of low-rate schedule behavior. Learn Mem 15:153-162. https://doi. org/10.1101/lm.729408

Combs JGF (2012) The vitamins: fundamental aspects in nutrition and health, 4th edn. Academic Press, London. https://doi.org/10.5860/choice.30-0327

Cooke RF, Del Rio NS, Caraviello DZ, Bertics SJ, Ramos MH, Grummer RR (2007) Supplemental choline for prevention and alleviation of fatty liver in dairy cattle. J Dairy Sci 90:2413-2418. https://doi.org/10.3168/jds.2006-028

Davidson S, Hopkins BA, Odle J, Brownie C, Fellner V, Whitlow LW (2008) Supplementing limited methionine diets with rumen-protected methionine, betaine, and choline in early lactation Holstein cows. J Dairy Sci 91:1552-1559. https://doi.org/10.3168/jds.2007-0721

Drackley JK, Dann HM, Douglas GN (2005) Physiological and pathological adaptations in dairy cows that may increase susceptibility to periparturient diseases and disorders. Ital J Anim Sci 4:323-344. https://doi. org/10.4081/ijas.2005.323

Eklund M, Bauer E, Wamatu J, Mosenthin R (2005) Potential nutritional and physiological functions of betaine in livestock. Nutr Res Rev 18:31-48. https://doi.org/10.1079/nrr200493

Elek P, Gaal T, Husveth F (2013) Influence of rumen-protected choline on liver composition and blood variables indicating energy balance in periparturient dairy cows. Acta Vet Hung 61:59-70. https://doi. org/10.1556/avet.2012.053

Elsawy G, Abdelrahman O, Hamza A (2014) Effect of choline supplementation on rapid weight loss and biochemical variables among female Taekwondo and Judo athletes. JHK 40:77-82. https://doi.org/10.2478/ hukin-2014-0009

Esposito G, Irons PC, Webb EC, Chapwanya A (2014) Interactions between negative energy balance, metabolic diseases, uterine health and immune response in transition dairy cows. Anim Reprod Sci 144:60-71. https://doi. org/10.1016/j.anireprosci.2013.11.007

Glier MBG, Timothy DJ, Angela M (2014) Methyl nutrients, DNA methylation, and cardiovascular disease. Mol Nutr Food Res 58:172-182. https://doi. org/10.1002/mnfr.201200636

Goselink R, van Baal J, Widjaja H (2012) Effect of rumen-protected choline supplementation on liver and adipose gene expression during the transition period in dairy cattle. J Dairy Sci 96:1102-1116. https://doi.org/10.3168/ jds.2012-5396

Goselink RMA, Van BJ, Widjaja HCA, Dekker RA, Zom RLG, Deveth MJ, Vanvuuren AM (2013) Impact of rumen-protected choline supplementation on liver and adipose gene expression during the transition period in dairy cattle. J Dairy Sci 96:1102-1116. https://doi.org/10.3168/jds.2012-5396

Grummer RR (1993) Etiology of lipid_related metabolic disorders in periparturient dairy cows. J Dairy Sci 76:3882-3896. https://doi.org/10.3168/jds. s0022-0302(93)77729-2

Grummer RR (2008) Nutritional and management strategies for the prevention of fatty liver in dairy cattle. J Vet 176:10-20. https://doi.org/10.1016/j. tvjl.2007.12.033

Guretzky NAJ, Carlson DB, Garrett JE, Drackley JK (2006) Lipid metabolite profiles and milk production for Holstein and jersey cows fed rumen protected choline during the periparturient period. J Dairy Sci 89:188-200. https://doi.org/10.3168/jds.s0022-0302(06)72083-5

Hartwell JR, Cecavqa MJ, Donkin SS (2000) Impact of dietary rumen undegradable protein and rumen-protected choline on intake, peripartum liver triacylglyceride, plasma metabolites and milk production in transition dairy cows. J Dairy Sci 83:2907-2917. https://doi.org/10.3168/jds. s0022-0302(00)75191-5

Henning SM, Swendseid ME, Ivandic BT (1997) Vitamins C, E and A and heme oxygenase in rats fed methyl folate-deficient diets. Free Radic Biol Med 23:936-942. https://doi.org/10.1016/s0891-5849(97)00097-x

Itle AJ, Huzzey JM, Weary DM, VonKeyserlingk MAG (2015) Clinical ketosis and standing behavior in transition cows. J Dairy Sci 98:128-134. https://doi. org/10.3168/jds.2014-7932

Jiang X, Yan J, Caudill MA (2014) Choline. In: Zempleni J, Suttie JW, Gregory III JF, Stover PJ (ed) Handbook of vitamins, 5th edn. CRC Press, Boca Raton, pp 491-513

Karimian M, Khorvash M, Forouzmand MA, Alikhani M, Rahmani HR, Ghaffari $\mathrm{MH}$ (2015) Effect of prepartal and postpartal dietary fat level on performance and plasma concentration of metabolites in transition dairy cows. J Dairy Sci 98:330-337. https://doi.org/10.3168/jds.2013-7577

Koc H, Mar MH, Ranasinghe A, Swenberg JA, Zeisel SH (2002) Quantitation of choline and its metabolites in tissues and foods by liquid chromatography/electrospray ionization-isotope dilution mass spectrometry. Anal Chem 74(18):4734-4740. https://doi.org/10.1021/ac025624x

Leach NV, Dronca E, Vesa SC (2014) Serum homocysteine levels, oxidative stress and cardiovascular risk in non-alcoholic steatohepatitis. Eur J Intern Med 25(8):762-767. https://doi.org/10.1515/rjim-2016-0035

LeBlanc SJ, Herdt TH, Seymour WM, Duffield TF, Leslie KE (2004) Pripartum serum vitamin $\mathrm{E}$, retinol, and beta-carotene in dairy cattle and their associations with disease. J Dairy Sci 87:609-619. https://doi.org/10.3168/ jds.s0022-0302(04)73203-8

Leiva T, Cooke R, Brandao A (2015) Effects of rumen protected choline supplementation on metabolic and performance responses of transition dairy cows. J Anim Sci 93:1896-1904. https://doi.org/10.2527/jas.2014-8606

Lima FS, Filho MFS, Greco LF, Susca F, Magalhaes VJ, Garrett J, Santos JEP (2007) Effects of feeding rumen-protected choline on lactation and metabolism. J Dairy Sci 90:174. https://doi.org/10.1016/j.tvjl.2011.09.019

Lima FS, Filho MFS, Greco F, Santos JEP (2012) Effects of feeding rumen protected choline on incidence of disease and reproduction of dairy cows. vet J 193:140-145. https://doi.org/10.1016/j.tvjl.2011.09.019 
Litherland NB, Dann HM, Drackley JK (2011) Prepartum nutrient intake alters palmitate metabolism by liver slices from peripartal dairy cows. J Dairy Sci 94:1928-1940. https://doi.org/10.3168/jds.2010-3220

Maison P, Byrne CD, Hales CN, Wareham NJ (2000) Hypertension and its treatment influence changes in fasting non-esterified fatty acid concentrations: a link between the sympathetic nervous system and the metabolic syndrome? Metabolism 49:81-87. https://doi.org/10.1016/ s0026-0495(00)90788-1

McNamara JP (1991) Regulation of adipose tissue metabolism in support of lactation. J Dairy Sci 74:706-719. https://doi.org/10.3168/jds. s0022-0302(91)78217-9

MIC (2017) Micronutrient Information Center [Choline], Linus Pauling Institute, Oregon State University, Corvallis, Oregon. Accessed Feb 2015

Noga AA, Vance DE (2003) A gender-specific role for phosphatidylethanolamine $\mathrm{N}$-methyltransferase-derived phosphatidylcholine in the regulation of plasma high density and very low-density lipoproteins in mice. J Biol Chem 278(24):21851-21859. https://doi.org/10.1074/jbc.m301982200

Noga AA, Zhao Y, Vance DE (2002) An unexpected requirement for phosphatidylethanolamine $\mathrm{N}$-methyltransferase in the secretion of very low-density lipoproteins. J Biol Chem 277(44):42358-42365. https://doi. org/10.1074/jbc.m204542200

NRC (2001) Nutrient requirements of dairy cattle. 7th rev. ed. Natl. Acad. Press, Washington, DC. https://doi.org/10.17226/9825

Osorio JS, Ji P, Drackley JK, Luchini D, Loor JJ (2013) Supplemental Smartamine M or MetaSmart during the transition period benefits post partal cow performance and blood neutrophil function. J Dairy Sci 96:6248-6263. https://doi.org/10.3168/jds.2013-96-12-8093

Osorio JS, Trevisi E, Ji P, Drackley JK, Luchini D, Bertoni G, Loor JJ (2014) Biomarkers of inflammation, metabolism, and oxidative stress in blood, liver, and milk reveal a better immune metabolic status in peripartal cows supplemented with Smartamine M or MetaSmart. J Dairy Sci 97:7437-7450. https://doi.org/10.3168/jds.2013-7679

Overton TR, Waldron MR (2004) Nutritional management of transition dairy cows: Strategies to optimize metabolic health. J Dairy Sci 87((E-Suppl.)):105-119. https://doi.org/10.3168/jds. s0022-0302(04)70066-1

Overton TR, Emmert LS, Clark JH (1998) Effects of source of carbohydrate and protein and rumen-protected methionine on performance of cows. J Dairy Sci 81:221-228. https://doi.org/10.3168/jds.s0022-0302(98)75569-9

Phillips MM (2012) Analytical approaches to determination of total choline in foods and dietary supplements. Anal Bioanal Chem 403:2103-2112. https://doi.org/10.1007/s00216-011-5652-5

Piepenbrink MS, Overton TR (2003) Liver metabolism and production of cows fed increasing amounts of rumen protected choline during the periparturient period. J Dairy Sci 86:1722-1733. https://doi.org/10.3168/ jds.s0022-0302(03)73758-8

Pineda A, Cardosa FC (2015) Effects of rumen protected choline with calcium salts of long chain fatty acids on milk yield and milk composition of middle and late lactation Holstein cows. Livest Sci 175:47-58. https://doi. org/10.1016/j.livsci.2015.02.005

Pinotti L, Baldi A, Politis I, Rebucci R, Sangalli L, Dellorto V (2003) Rumenprotected choline administration to transition cows: effects on milk production and vitamin E status. J Vet Med Ser A 50:18-21. https://doi. org/10.1046/j.1439-0442.2003.00502.x

Reynolds CK, Aikman PC, Lupoli B (2003) Splanchnic metabolism of dairy cows during the transition from late, gestation through early lactation. J Dairy Sci 86:1201-1217. https://doi.org/10.3168/jds.s0022-0302(03)73704-7

Sales J, Homolka P, Koukolova V (2010) Effect of dietary rumen protected choline on milk production of dairy cows: a meta-analysis. J Dairy Sci 93:3746-3754. https://doi.org/10.3168/jds.2010-3106

Sejersen H, Sorensen MT, Larsen T, Bendixen E, Ingvartsen KL (2012) Liver protein expression in dairy cows with high liver triglycerides in early lactation. J Dairy Sci 95:2409-2421. https://doi.org/10.3168/jds.201 1-4604

Sheard NF, Zeisel SH (1986) An in vitro study of choline uptake by intestine from neonatal adult rats. Pediatr Res 20:768-772. https://doi. org/10.1203/00006450-198608000-00014
Siljander RH, Peuranen S, Tiihonen K, Virtanen E, Kettunen H, Alaviuhkola T, Simmins P (2003) Effect of equi-molar dietary betaine and choline addition on performance, carcass quality and physiological parameters of pigs. Anim Sci 76:55-62. https://doi.org/10.1017/s1357729800053315

Soltan MA, Mujalli AM, Mandour MA, Abeer ME (2012) Effect of dietary rumen protected methionine and/or choline supplementation of rumen fermentation characteristics and protective performance of early lactating cows. Pak J Nutr 11(3):221-230. https://doi.org/10.3923/pjn.2012.221.230

Strang BD, Bertics SJ, Grummer RR, Armentano LE (1998) Effect of longchain fatty acids on triglycerides accumulation, gluconeogenesis, and ureagenesis in bovine hepatocytes. J Dairy Sci 81:728-739. https://doi. org/10.3168/jds.50022-0302(98)75629-2

Sun F, Cao Y, Cai C, Li S, Yu C, Yao Y (2016) Regulation of nutritional metabolism in transition dairy cows: energy homeostasis and health in response to post-ruminal choline and methionine. PLoS ONE 11:160-659. https://doi. org/10.1371/journal.pone.0160659

Turk R, Podpecan O, Mrkun J, Kosec M, Flegar-Mestric Z, Perkov S (2013) Lipid mobilisation and oxidative stress as metabolic adaptation processes in dairy heifers during transition period. Anim Reprod Sci 141:109-115. https://doi.org/10.1016/j.anireprosci.2013.07.014

Veth MJD, Artegoitia VM, Campagna SR, Lapierre H, Harte F, Girard CL (2016) Choline absorption and evaluation of bioavailability markers when supplementing choline to lactating dairy cows. J Dairy Sci 99:1-13. https:// doi.org/10.3168/jds.2016-11382

Wu P, Jiang J, Liu Y, Hu K, Jiang WD, Li SH (2013) Dietary choline modulates immune responses, and gene expressions of TOR and elF4E-binding protein 2 in immune organs of juvenile Jian carp (Cyprinus carpio var. Jian). Fish Shellfish Immunol 35:697-706. https://doi.org/10.1016/j. fsi.2013.05.030

Wua P, Jianga W, Liua Y, Chena G, Jiangb J, Lib S, Fenga L, Zhoua X (2014) Effect of choline on antioxidant defenses and gene expressions of Nrf2 signaling molecule in the spleen and head kidney of juvenile Jian carp (Cyprinus carpio var. Jian). Fish Shellfish Immunol 38:374-382. https://doi. org/10.1016/j.fsi.2014.03.032

Xu S, Harrison JH, Chalupa W, Sniffen CJ, Julien W (1998) The effect of ruminal bypass lysine and methionine on milk yield and composition of lactating cows. J Dairy Sci 81:1062-1077. https://doi.org/10.3168/jds. s0022-0302(98)75668-1

X U G, Ye JA, Liu J, Yu Y (2006) Effect of rumen protected choline addition on milk performance and blood metabolic parameters in transition dairy cows. Asian Australas J Anim Sci 19(3):390-395. https://doi.org/10.5713/ ajas. 2006.390

Zahra LC, Duffleld TF, Leslle KE, Overton TR, Putnam D, Leblanc J (2006) Effects of rumen protected choline and monensin on milk production and metabolism of periparturient dairy cows. J Dairy Sci 89:4808-4818. https://doi.org/10.1017/s1751731108002917

Zeisel SH (2000) Choline: an essential nutrient for humans. Nutrition 16:669671. https://doi.org/10.1016/s0899-9007(00)00349-x

Zeisel S (2017) Choline, other methyl-donors and epigenetics. Nutrients 9:445. https://doi.org/10.3390/nu9050445

Zeisel SH, Corbin KD (2012) Choline. present knowledge in nutrition, 10th edn. Wiley, New York, pp 405-418. https://doi.org/10.1002/9781119946045. ch26

Zeisel SH, Da Costa KA (2009) Choline: an essential nutrient for public health. Nutr Rev 67(11):615-623. https://doi. org/10.1111/j.1753-4887.2009.00246.x

Zhang J, Holt RI, Wild SH, Poole RB, Holt H, Byrne CD (2005) Plasma adiponectin concentrations are independently predicted by fat insulin sensitivity in women and by muscle insulin sensitivity in men. Diabetes Care 28:755-756. https://doi.org/10.2337/diacare.28.3.755

Zom RLG, Baal JV, Goselink RMA, Bakker JA, Veth MJ, Vuuren AM (2011) Effect of rumen protected choline on performance, blood metabolites, and hepatic triacylglycerols of periparturient dairy cattle. J Dairy Sci 94:4016-4027. https://doi.org/10.3168/jds.2012-95-1-496 